\title{
Instalasi Open Journal System (OJS) Versi 3 Sebagai Pendukung Kegiatan Pengelolaan dan Publikasi Jurnal Ilmiah
}

\author{
Nurlaila Suci Rahayu Rais ${ }^{1}$ \\ Ruli Supriati ${ }^{2}$ \\ Siti Ika Danti ${ }^{3}$

\begin{abstract}
Dosen Perguruan Tinggi Raharja ${ }^{1,2}$
Mahasiswa Perguruan Tinggi Raharja Jurusan Manajemen Informatika ${ }^{3}$

E-mail : nurlaila@raharja.info ${ }^{1}$,ruli@raharja.info ${ }^{2}$,danti@raharja.info ${ }^{3}$
\end{abstract}

\begin{abstract}
ABSTRAK
Open Journal System (OJS) merupakan perangkat lunak open source yang digunakan untuk mengelola jurnal ilmiah secara online. OJS dikembangkan oleh Public Knowledge Project sejak tahun 2001. OJS versi terbaru yaitu OJS versi 3 dirilis pada tahun 2016. Tujuan penelitian ini adalah untuk memahami cara instalasi OJS versi 3 serta untuk mengetahui kelebihan OJS versi 3 yang dapat mendukung kegiatan pengolahan dan publikasi jurnal ilmiah elektronik (e-journal). Metode penelitian yang digunakan yaitu analisis kebutuhan dalam proses instalasi OJS dan flowchart yang menjelaskan tahap-tahap instalasi OJS.
\end{abstract}

Kata Kunci : Instalasi, OJS, publikasi, e-journal.

\section{ABSTRACT}

Open Journal System (OJS) is an open source software used to manage online journals. OJS was developed by the Public Knowledge Project since 2001. The latest version of OJS is OJS version 3 was released in 2016. The purpose of this research is to understand how to install OJS version 3, and to know the advantages of OJS version 3 which can support the processing and publication of electronic journals (e-journal). The research method used is requirement analysis in installation process of OJS and flowchart which explain the stages of OJS installation.

Keyword : Installation, OJS, publication, e-journal.

\section{PENDAHULUAN}

Berdasarkan Perdirjen Nomor 49/Dikti/Kep/2011 Tentang Pedoman Akreditasi Terbitan Berkala Ilmiah, serta Surat Kebijakan Unggah Karya Ilmiah dan Jurnal Nomor 2050/E/T/2011 yang menyatakan bahwa "Dirjen Dikti tidak akan melakukan penilaian karya ilmiah yang dipublikasikan di suatu jurnal jika artikel dan identitas jurnal yang bersangkutan tidak bisa ditelusuri secara online”. Maka pengelolaan dan publikasi jurnal ilmiah secara online menjadi suatu hal yang sangat penting, sehingga diperlukan sistem yang dapat digunakan untuk mendukung pengelolaan dan publikasi jurnal ilmiah secara online. 
Open Journal System (OJS) merupakan perangkat lunak open source yang digunakan untuk mengelola jurnal ilmiah secara online. OJS dikembangkan oleh Public Knowledge Project sejak tahun 2001. Fitur yang terdapat pada OJS mulai dari sebuah artikel dikirim oleh penulis (Author), proses review oleh Reviewer, dan lain sebagainya hingga artikel tersebut diterima untuk diterbitkan dalam sebuah jurnal. OJS versi terbaru yaitu OJS versi 3 dirilis pada tahun 2016. Tujuan dari penelitian ini adalah untuk memahami cara instalasi OJS versi 3 serta untuk mengetahui kelebihan OJS versi 3 yang dapat mendukung kegiatan pengolahan dan publikasi jurnal ilmiah elektronik (e-journal).

\section{PERMASALAHAN}

Terdapat 3 (tiga) permasalahan yang dihadapi dalam penelitian ini, yaitu:

1. Kebutuhan apa saja yang diperlukan untuk melakukan instalasi Open Journal System (OJS) versi 3?

2. Bagaimana cara instalasi Open Journal System (OJS) versi 3?

3. Apa saja kelebihan OJS versi 3 yang dapat mendukung kegiatan pengelolaan dan publikasi jurnal ilmiah?

\section{METODOLOGI PENELITIAN}

\section{Analisis Kebutuhan}

Metode yang digunakan dalam penelitian ini adalah menganalisis kebutuhan dalam proses instalasi Open Journal System (OJS) versi 3 yang terdiri dari:

1. Web Browser

Menurut Aryani dkk. (2015:5) [1], “Web Browser adalah suatu program atau software yang digunakan untuk menjelajahi internet atau untuk mencari informasi dari suatu web yang tersimpan di dalam komputer". Contoh web browser yaitu Internet Explorer, Chrome, FireFox, Opera, Safari, Lynx, dll. Web browser yang digunakan pada penelitian ini adalah Chrome.

2. Akun Web Hosting

Menurut Ariyus dan Anggara (2018:20) [2], "Web Hosting adalah salah satu bentuk layanan jasa penyewaan tempat di internet yang memungkinkan perorangan maupun organisasi menampilkan layanan jasa atau produknya di web atau situs internet". Requirement yang perlu diperhatikan adalah:

a. Versi PHP harus menggunakan PHP $>=5.6 .0$

Menurut Rahayu dkk. (2018:57) [3], "Script PHP merupakan bahasa web server side yang bersifat open source. Bahasa PHP menyatu dengan script HTML yang sepenuhnya dijalankan pada server".

b. MySQL >= 4.1 atau PostgreSQL >=9.1.5

Menurut Rahayu dkk. (2018:58) [3], "MySQL adalah database yang menghubungkan script PHP menggunakan perintah query dan escape character yang sama dengan PHP".

c. Apache $>=1.3 .2 \mathrm{x}$ atau $>=2.0 .4 \mathrm{x}$ atau Microsoft IIS 6

d. Serta sistem operasi yang mendukung OJS yaitu Linux, BSD, Solaris, Mac OS X, dan Windows. 


\section{Software OJS}

Software untuk instalasi OJS versi 3 dapat di-download secara gratis pada halaman berikut https $/ /$ pkp.sfu.ca/ojs/ojs_download/. Pada penelitian ini menggunakan software OJS versi 3.1.1 yang dirilis pada tanggal 4 April 2018.

\section{Flowchart Instalasi OJS}

Setelah menganalisis dan mempersiapkan kebutuhan untuk instalasi OJS versi 3. Tahap-tahap yang dilakukan dalam proses instalasi OJS versi 3 dapat dilihat pada flowchart berikut ini:
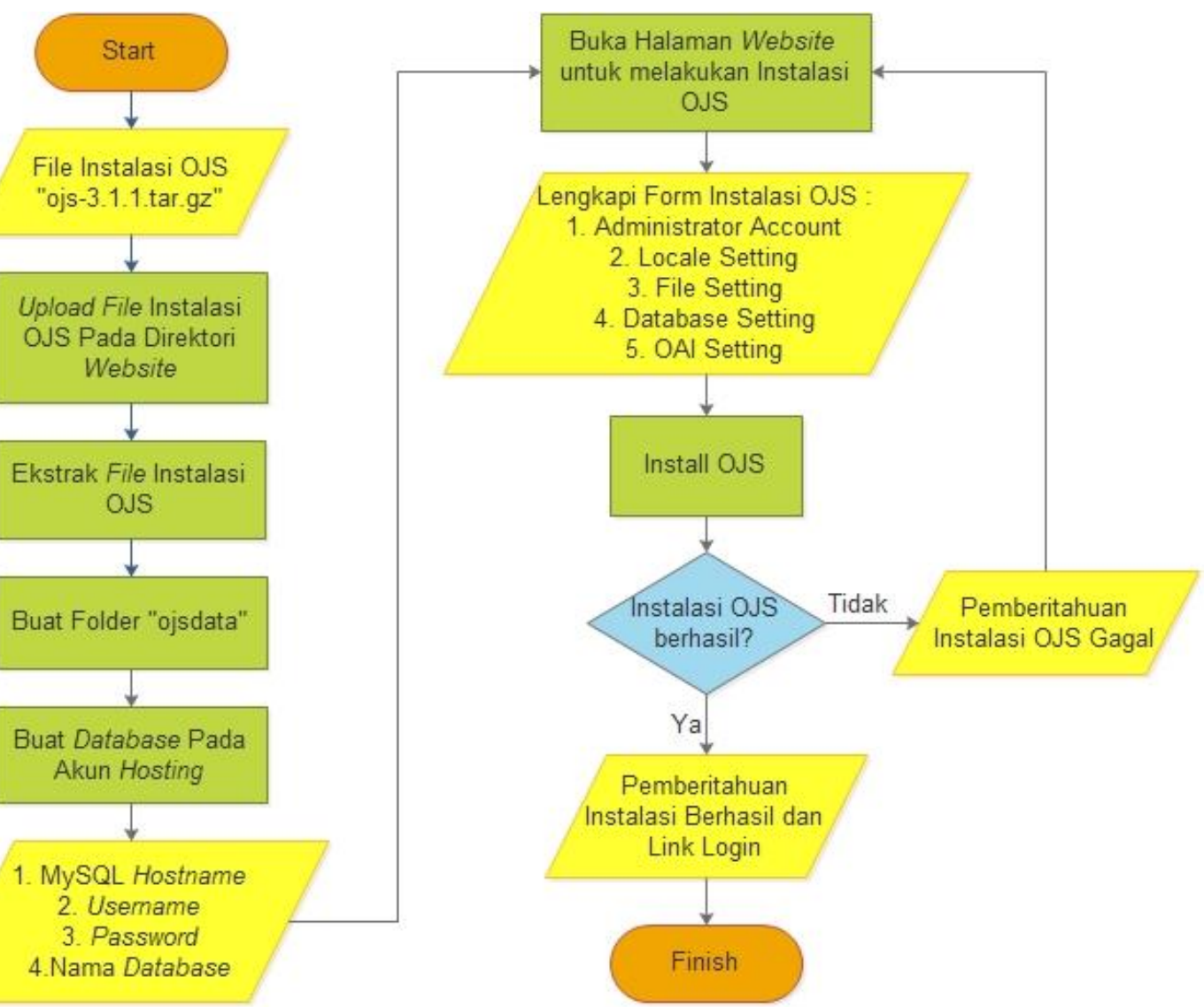

Gambar 1. Flowchart Instalasi OJS.

Penjelasan untuk flowchart instalasi OJS versi 3 pada gambar di atas adalah sebagai berikut:

1. Upload file instalasi OJS.

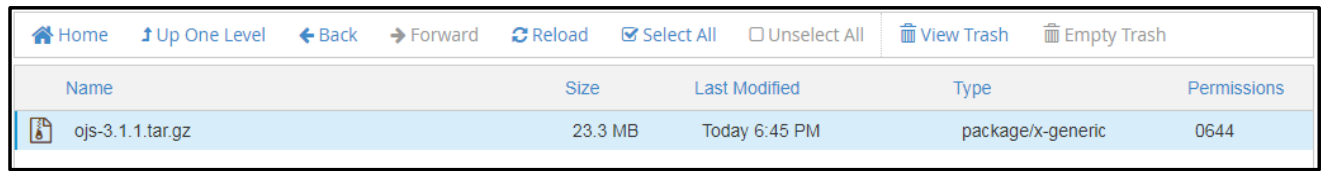

Gambar 2. Upload File Instalasi OJS.

Mengupload file instalasi OJS versi 3 (ojs-3.1.1.tar.gz) pada direktori website yang akan dijadikan sebagai tempat instalasi OJS.

2. Ekstrak file instalasi OJS. 


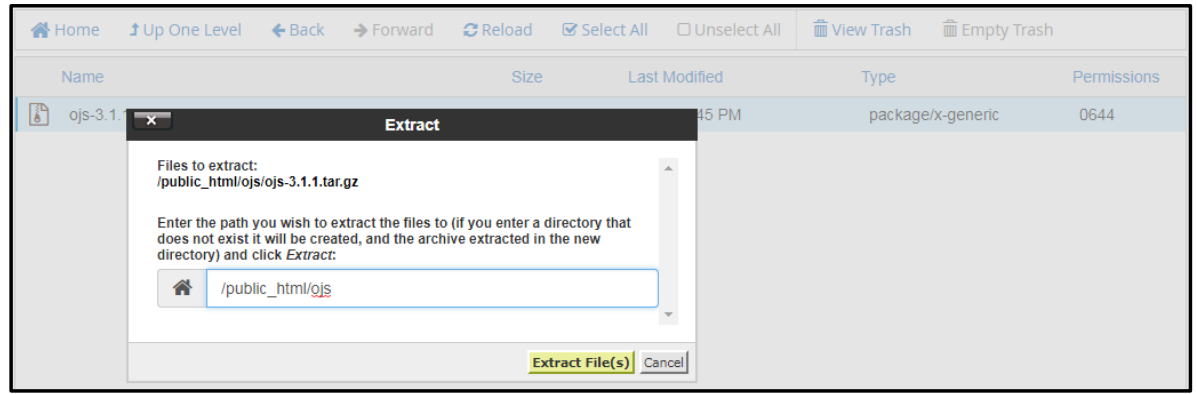

Gambar 3. Ekstrak File Instalasi OJS.

Mengekstrak file instalasi OJS versi 3 (ojs-3.1.1.tar.gz) yang telah diupload pada direktori website.

3. Buat folder "ojsdata".

\begin{tabular}{|c|c|c|c|c|c|c|c|}
\hline \multirow{2}{*}{\multicolumn{2}{|c|}{$\begin{array}{r}\text { న Home } \\
\text { Name }\end{array}$}} & \multirow{2}{*}{$\leftarrow$ Back } & \multirow{2}{*}{$\rightarrow$ Forward } & \multirow{2}{*}{$\begin{array}{r}\approx \text { Reload } \\
\text { Size }\end{array}$} & \multirow{2}{*}{$\begin{array}{c}\nabla \text { Select All } \quad \text { QUnselect All } \\
\text { Last Modified }\end{array}$} & \multirow{2}{*}{$\begin{array}{c}\text { 盢 View Trash } \\
\text { Type }\end{array}$} & \\
\hline & & & & & & & Permissions \\
\hline & & & & $4 \mathrm{~KB}$ & Apr 5, 2018 5:57 AM & httpd/unix-directory & 0755 \\
\hline ta & cache & & & $4 \mathrm{~KB}$ & Apr 5, 2018 6:01 AM & httpd/unix-directory & 0755 \\
\hline a & classes & & & $4 \mathrm{~KB}$ & Apr 5, 2018 5:57 AM & httpd/unix-directory & 0755 \\
\hline e & controllers & & & $4 \mathrm{~KB}$ & Apr 5, 2018 5:57 AM & httpd/unix-directory & 0755 \\
\hline 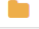 & dbscripts & & & $4 \mathrm{~KB}$ & Apr 5, 2018 5:57 AM & httpd/unix-directory & 0755 \\
\hline 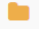 & docs & & & $4 \mathrm{~KB}$ & Apr 5, 2018 6:01 AM & httpd/unix-directory & 0755 \\
\hline e & js & & & $4 \mathrm{~KB}$ & Apr 5, 2018 6:01 AM & httpd/unix-directory & 0755 \\
\hline 0 & lib & & & $4 \mathrm{~KB}$ & Apr 5, 2018 6:01 AM & httpd/unix-directory & 0755 \\
\hline n & locale & & & $4 \mathrm{~KB}$ & Apr 5, 2018 5:57 AM & httpd/unix-directory & 0755 \\
\hline E & ojsdata & & & $4 \mathrm{~KB}$ & Today 6:49 PM & httpd/unix-directory & 0755 \\
\hline a & pages & & & $4 \mathrm{~KB}$ & Apr 5, 2018 5:57 AM & httpd/unix-directory & 0755 \\
\hline 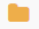 & plugins & & & $4 \mathrm{~KB}$ & Apr 5, 2018 5:57 AM & httpd/unix-directory & 0755 \\
\hline a & public & & & $4 \mathrm{~KB}$ & Apr 5, 2018 6:01 AM & httpd/unix-directory & 0755 \\
\hline n & registry & & & $4 \mathrm{~KB}$ & Apr 5, $20185: 57$ AM & httpd/unix-directory & 0755 \\
\hline $\mathrm{E}$ & styles & & & $4 \mathrm{~KB}$ & Apr 5, 2018 6:01 AM & httpd/unix-directory & 0755 \\
\hline
\end{tabular}

Gambar 4. Buat Folder "ojsdata".

Membuat folder/direktori baru dengan nama folder/direktori "ojsdata" sebagai tempat penyimpanan data-data jurnal yang akan diunggah.

4. Buat database baru.

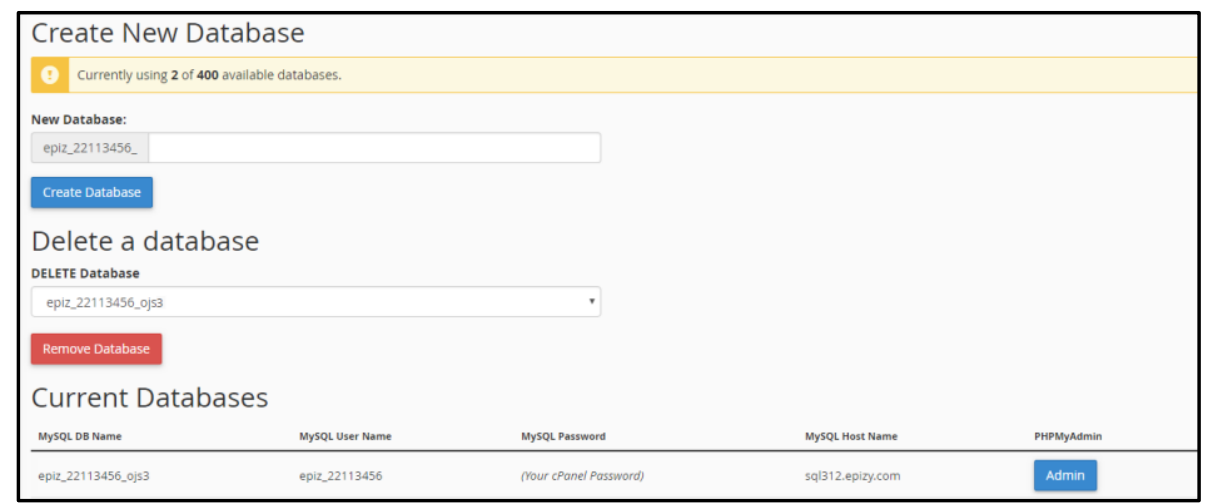

Gambar 5. Buat Database Baru.

Membuat database baru pada akun hosting, kemudian data MySQL database name, MySQL user name, MySQL password dan MySQL host name digunakan untuk melengkapi form pada proses instalasi OJS.

5. Buka halaman website untuk melakukan instalasi OJS. 


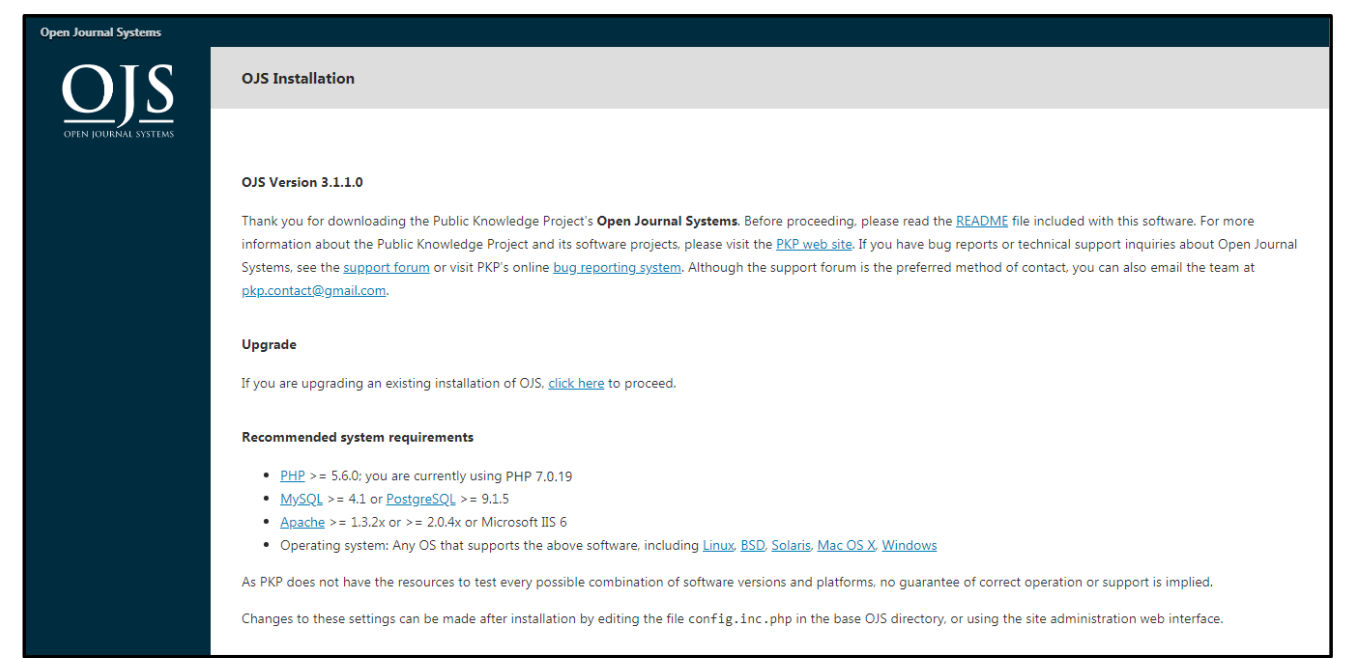

Gambar 6. Halaman Instalasi OJS.

Membuka halaman website untuk melakukan instalasi OJS, kemudian melengkapi form instalasi OJS yang terdiri dari:

a. Administrator Account.

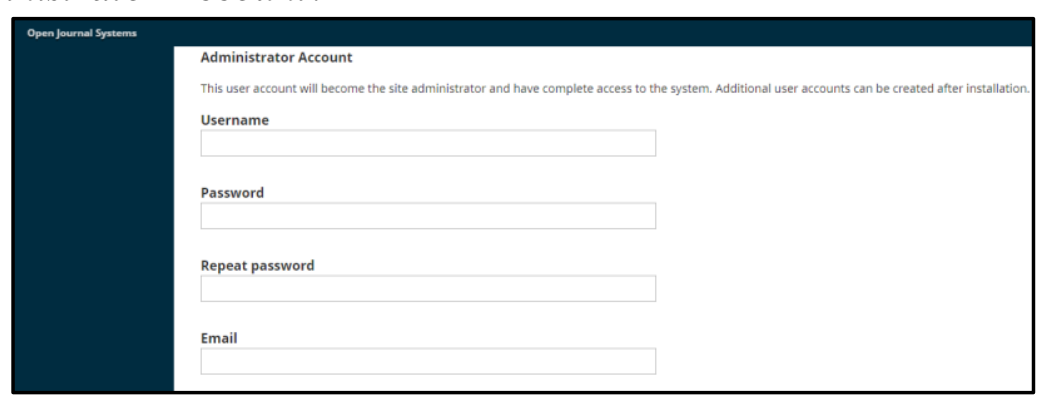

Gambar 7. Form Administrator Account.

Akun pengguna ini akan menjadi administrator situs dan memiliki akses lengkap pada sistem. Akun pengguna tambahan dapat dibuat setelah instalasi.

b. Locale Settings.

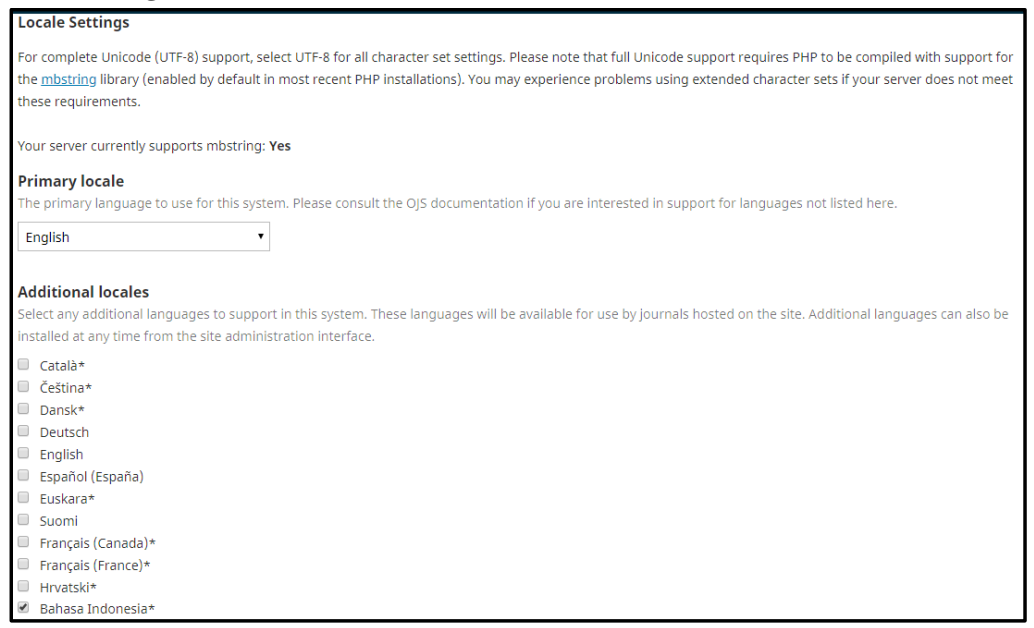

Gambar 8. Form Locale Settings.

Primary locale merupakan bahasa utama yang digunakan pada sistem, disarankan untuk memilih bahasa inggris karena terjemahan untuk bahasa Indonesia masih belum lengkap. Sedangkan bahasa 
Indonesia dapat dipilih pada Additional locales yaitu bahasa tambahan juga dapat di-install kapan saja melalui halaman administrasi situs.

c. File Settings.

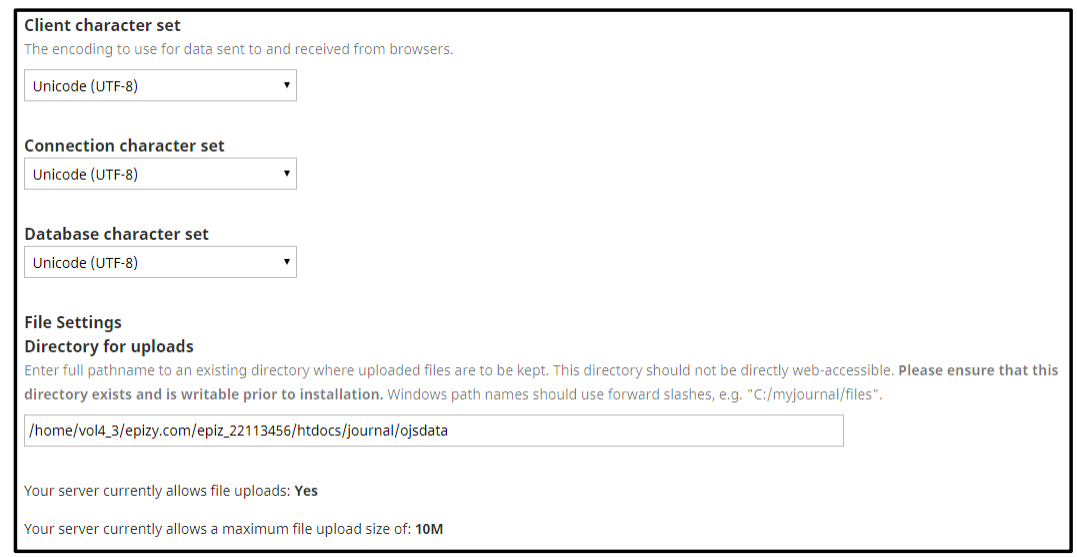

Gambar 9. Form File Settings.

Masukkan nama path lengkap ke direktori yang ada di mana data yang diunggah harus disimpan. Isikan nama path folder/direktori "ojsdata" yang sudah dibuat sebelumnya pada gambar 4. Nama path harus menggunakan garis miring misalnya "C $/$ myjournal/file".

d. Database Settings.

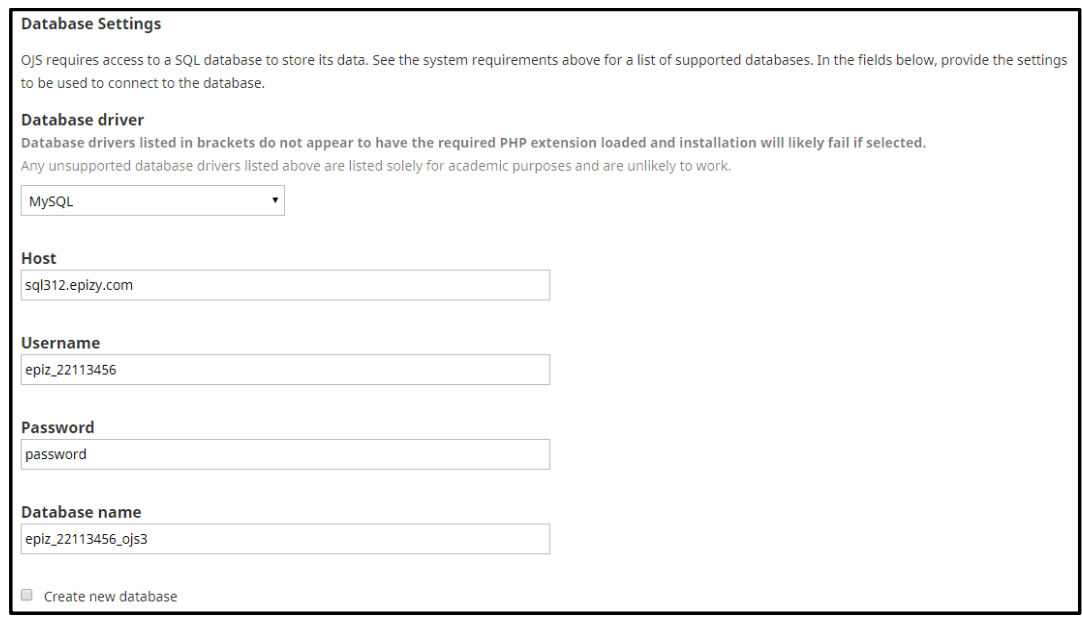

Gambar 10. Form Database Settings.

Berikan pengaturan yang digunakan untuk menghubungkan ke database dengan cara mengisi MySQL host name, MySQL user name, MySQL password, dan MySQL database name sesuai dengan database yang sudah dibuat sebelumnya pada gambar 5 .

e. OAI Settings.

OAI Settings
Repository Identifier
A unique identifier used to identify metadata records indexed from this site using the Open Archives Initiative Protocol for Metadata Harvesting.
ojs2.journalsystem.rf.gd
Beacon
Provide a unique site ID and OAI base URL to PKP for statistics and security alert purposes only.

Gambar 11. Form OAI Settings.

OAI Settings merupakan pengenal unik yang digunakan untuk mengidentifikasi catatan metadata yang diindeks dari situs ini 
menggunakan Protokol Open Archives Initiative untuk Metadata Harvesting (pengumpulan metadata).

\section{Install OJS}

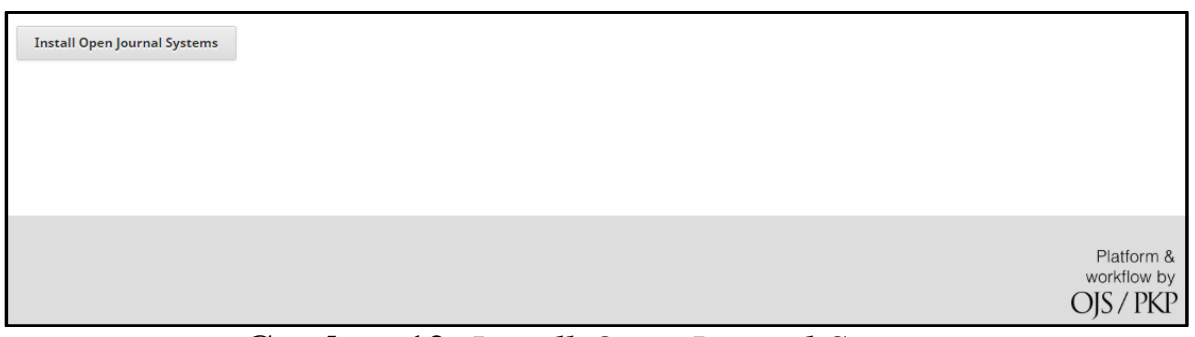

Gambar 12. Install Open Journal System.

Setelah melengkapi form instalasi OJS, klik "Install Open Journal System" dan tunggu hingga proses instalasi selesai.

7. Kemudian setelah proses instalasi OJS berhasil dilakukan, akan tampil pemberitahuan instalasi OJS berhasil.

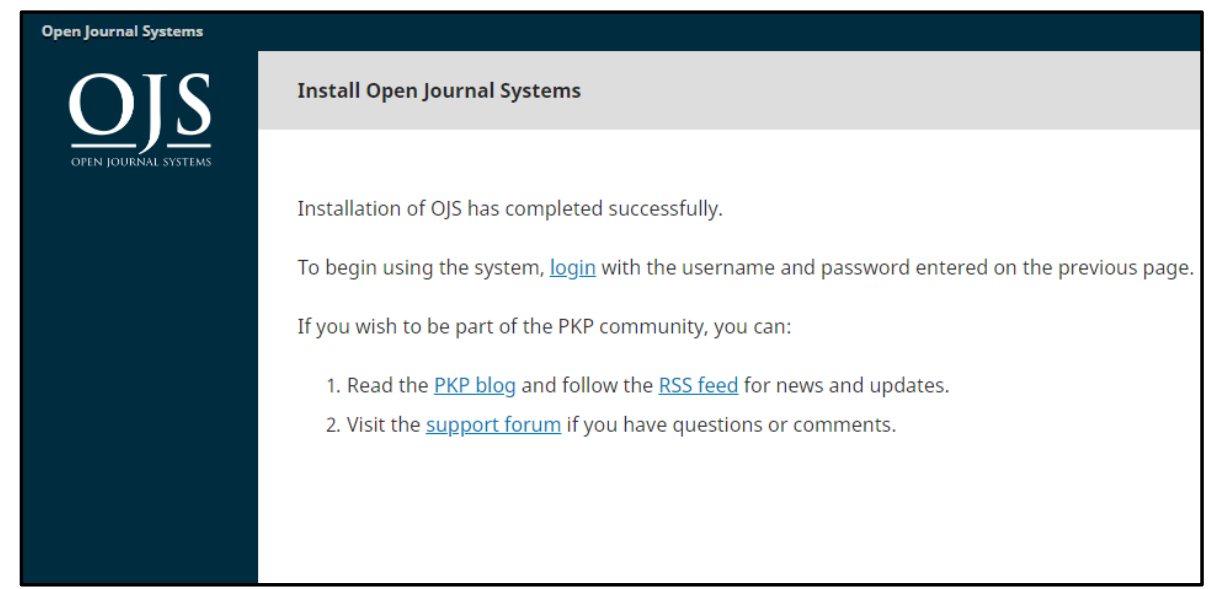

Gambar 13. Pemberitahuan Instalasi OJS Berhasil.

Tampil pemberitahuan "Installation of OJS has completed successfully", untuk menjalankan sistem, klik link "login" dan melakukan login menggunakan username dan password yang sudah didaftarkan pada saat mengisi form instalasi OJS bagian Administrator Account.

\section{LITERATURE REVIEW}

Literature review merupakan ulasan tentang penelitian yang telah dilakukan sebelumnya yang berkaitan dengan permasalahan dalam penelitian dan bertujuan untuk mendapatkan landasan teori yang dapat mendukung pemecahan masalah yang sedang diteliti. Adapun 4 (empat) literature review yang memiliki hubungan searah dengan penelitian ini adalah sebagai berikut:

1. Penelitian dengan judul "Perancangan Dan Pembuatan E-journal Menggunakan Open Journal System Di STMIK Jenderal Achmad Yani Yogyakarta" yang dilakukan oleh Mufti Baihaqi dan Ahmad Hanafi (2015) [4]. Permasalahan yang dihadapi pada penelitian tersebut yaitu proses-proses dalam penerbitan jurnal dilakukan secara terpisah, memakan waktu yang lama dan menyulitkan dalam proses koordinasi. Selain 
itu karya tulis terbitan Jurnal Teknomatika belum bisa diakses secara online. Solusi untuk permasalahan tersebut yaitu membangun sistem e-journal menggunakan OJS versi 2.4.3 yang sesuai dengan kebutuhan pengelolaan dan penerbitan e-journal.

2. Penelitian yang dilakukan oleh Nur Hadi Wijaya (2017) [5] yang berjudul "Pengembangan E-journal Hasil Penelitian Mahasiswa Fakultas Ilmu Kesehatan Universitas Respati Yogyakarta". Tujuan penelitian tersebut adalah untuk mengembangkan e-journal (jurnal elektronik) hasil penelitian mahasiswa pada Fakultas Ilmu Kesehatan Universitas Respati Yogyakarta. Hasil yang diperoleh yaitu menggunakan Open Journal System versi 2 untuk publikasi karya ilmiah atau hasilhasil penelitian mahasiswa dikategorikan berdasarkan pada program studi yang terdapat di Fakultas Ilmu Kesehatan Universitas Respati Yogyakarta.

3. Penelitian yang dilakukan oleh Noer Fajrin, Lia Kamelia, Tutun Juhana (2016) [6] dengan judul penelitian "Instalasi dan Implementasi Open Journal System di Local Area Network Laboratorium Telematika STEI-ITB”. Penelitian ini bertujuan untuk memahami dan mengetahui cara instalasi dan implementasi OJS yang berupa simulasi penerbitan sebuah jurnal pada OJS, kemudian dapat diakses secara bebas oleh seluruh pengguna yang terkoneksi dengan LAN Laboratorium Telematika STEI-ITB. Namun pada penelitian tersebut masih menggunakan OJS versi 2.4.8.

4. Penelitian yang dilakukan oleh Maulana Sani (2016) [7] yang berjudul "Penerapan iLearning Journal Center (iJC) Berbasis Open Journal System (OJS) Sebagai Media Penerbitan E-Journal Pada Perguruan Tinggi”. Salah satu tujuan dari penelitian ini yaitu untuk menghasilkan sistem yang dapat menerbitkan jurnal yang sesuai dengan ketentuan "Akreditasi Terbitan Berkala Ilmiah" yang terdapat pada surat edaran Kementerian Riset, Teknologi, Dan Pendidikan Tinggi Direktorat Pengelolaan Kekayaan Intelektual Nomor : 002/E.5/PB/I/2016 Jakarta, tanggal 19 Januari 2016. Namun terdapat perbedaan yaitu pada penelitian yang dilakukan oleh Maulana Sani masih menggunakan OJS versi 2.4.8.0.

5. Penelitian berjudul "Pemanfaatan Sistem iJC Berbasis OJS Sebagai Media E-Journal Pada STISIP YUPPENTEK" yang dilakukan oleh Indri Handayani, Qurotul Aini dan Novita Sari (2018) [8]. Permasalahan yang dibahas yaitu artikel ilmiah pada STISIP YUPPENTEK belum memenuhi syarat ketentuan Dikti perihal akreditasi jurnal yang mengharuskan jurnal dikelola dengan cara online, sehingga pengelolaan jurnal dapat dilakukan dengan lebih mudah dan cepat. Solusi untuk permasalahan tersebut adalah memanfaatkan sistem OJS yang memudahkan pengguna yaitu pengelola jurnal, penulis dan pembaca, sehingga proses pengelolaan jurnal dapat lebih mudah dan cepat. Namun penelitian tersebut masih menggunakan OJS versi 2.

\section{HASIL DAN PEMBAHASAN}

\section{Halaman Login OJS}




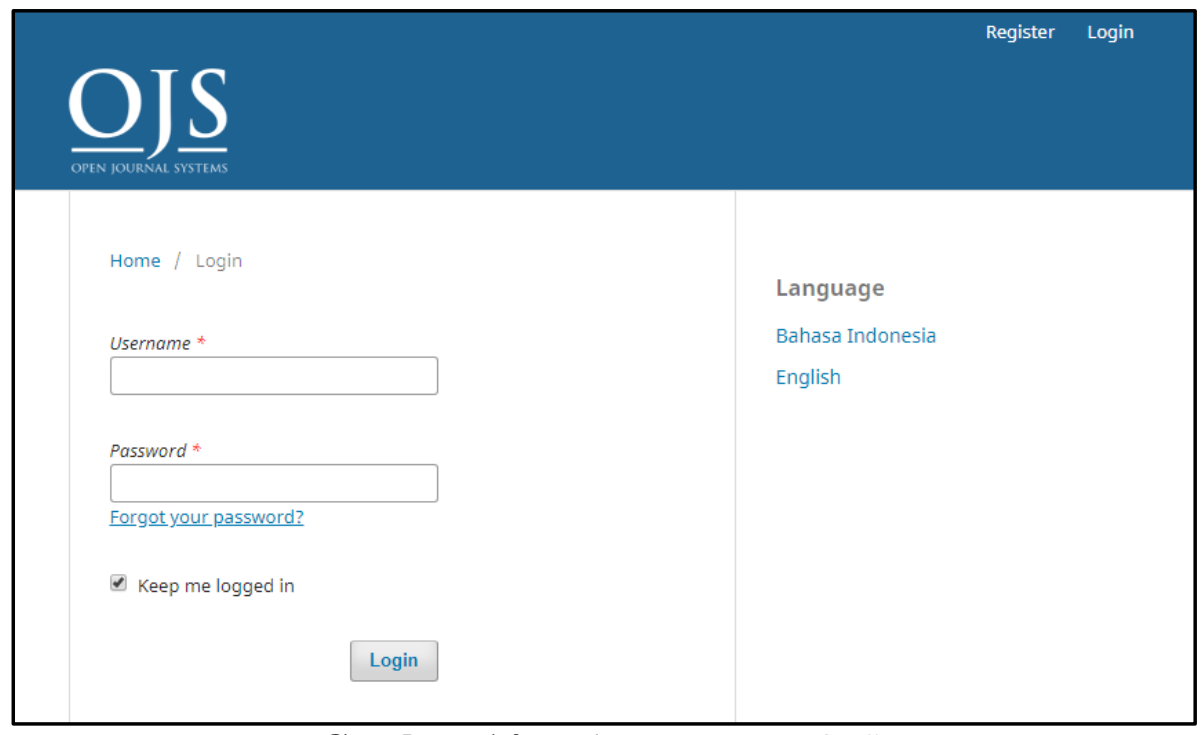

Gambar 14. Halaman Login OJS.

Gambar 14 di atas adalah tampilan halaman Login setelah melakukan proses instalasi OJS. Pada halaman Login ini hanya Admin yang dapat melakukan Login dengan menggunakan Username dan Password Administrator Account. Pengguna lain seperti Author, Editor, dan Reviewer dapat melakukan registrasi akun setelah Admin membuat halaman jurnal yang dikelola.

2. Halaman Hosted Journal

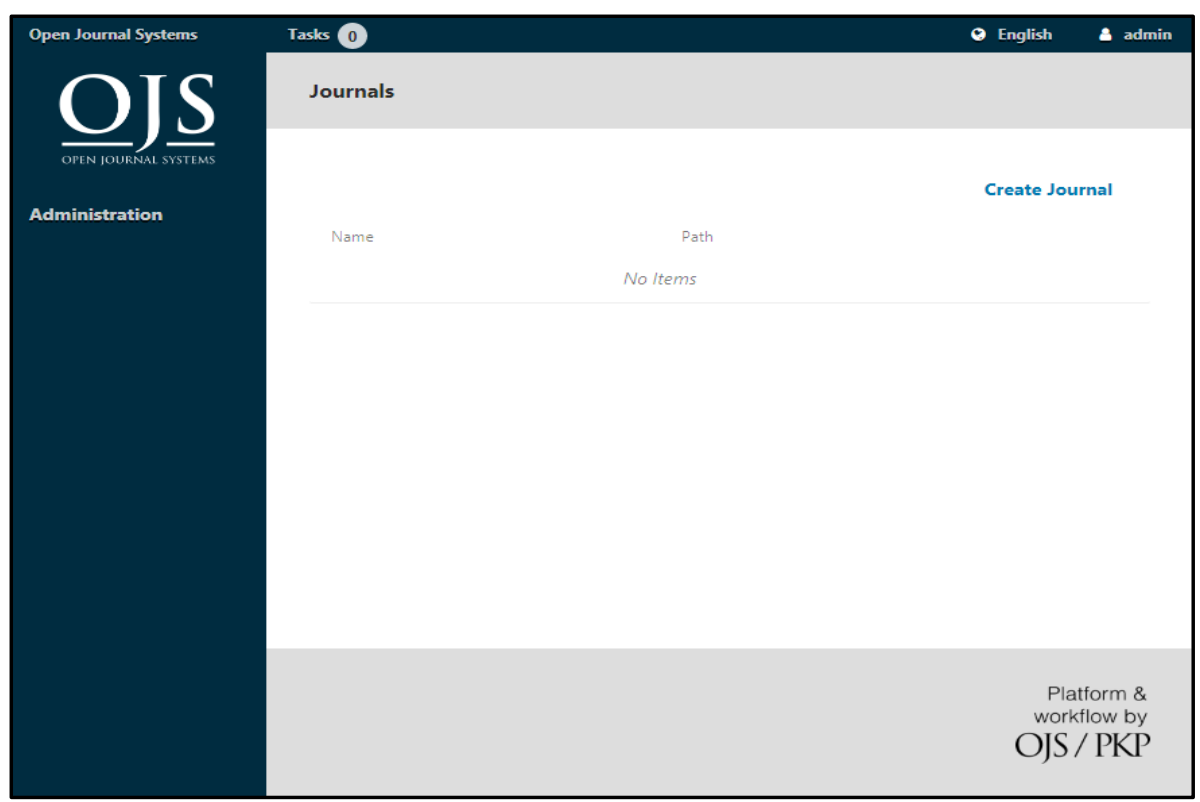

Gambar 15. Halaman Hosted Journal.

Setelah Admin berhasil melakukan Login, kemudian selanjutnya akan tampil halaman Hosted Journal. Pada halaman Hosted Journal ini, Admin dapat membuat halaman jurnal yang akan dikelola dengan cara klik Create Journal.

3. Halaman Setting Wizard 


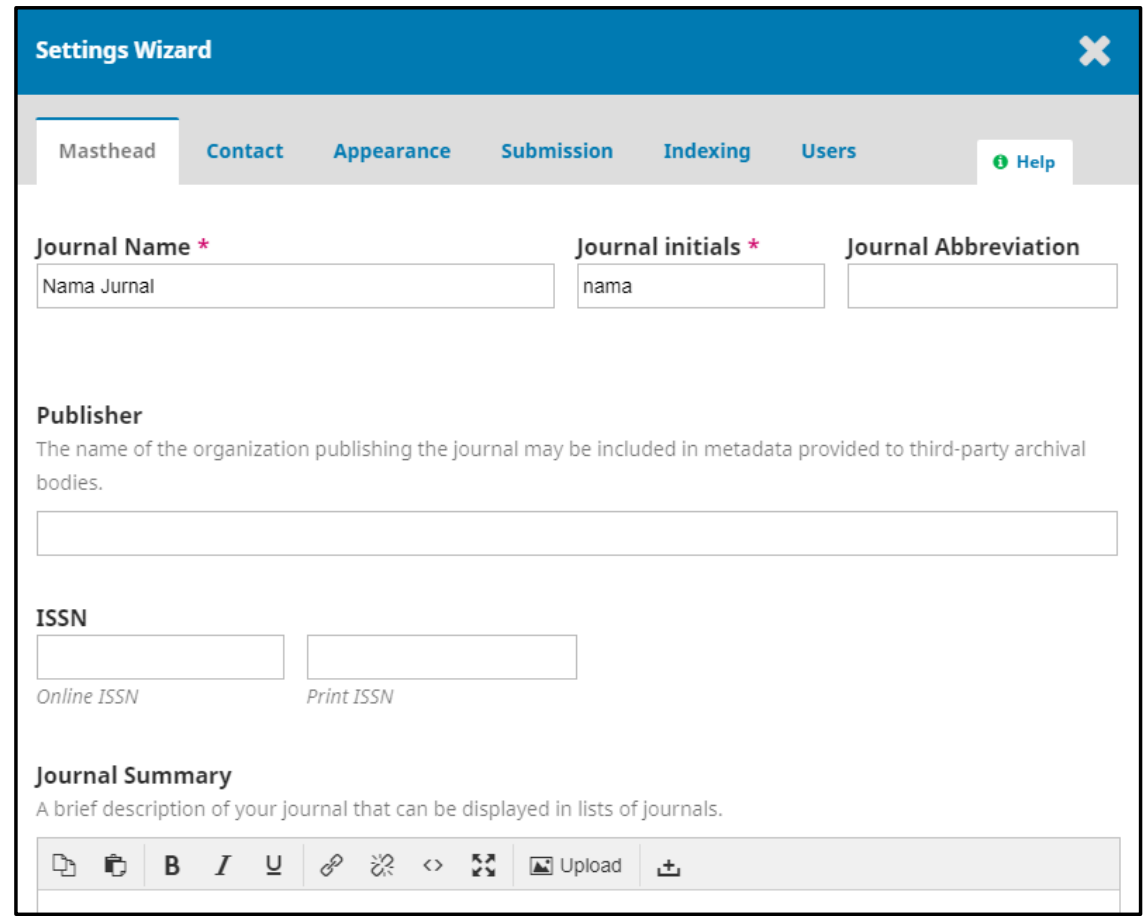

Gambar 16. Halaman Settings Wizard.

Setelah berhasil melakukan Create Journal maka kemudian akan tampil halaman Setting Wizard. Pada halaman ini Admin dapat melengkapi identitas jurnal, kontak jurnal, mengatur tampilan jurnal, pengaturan submissions, indeksasi dan users.

4. Halaman Home Jurnal

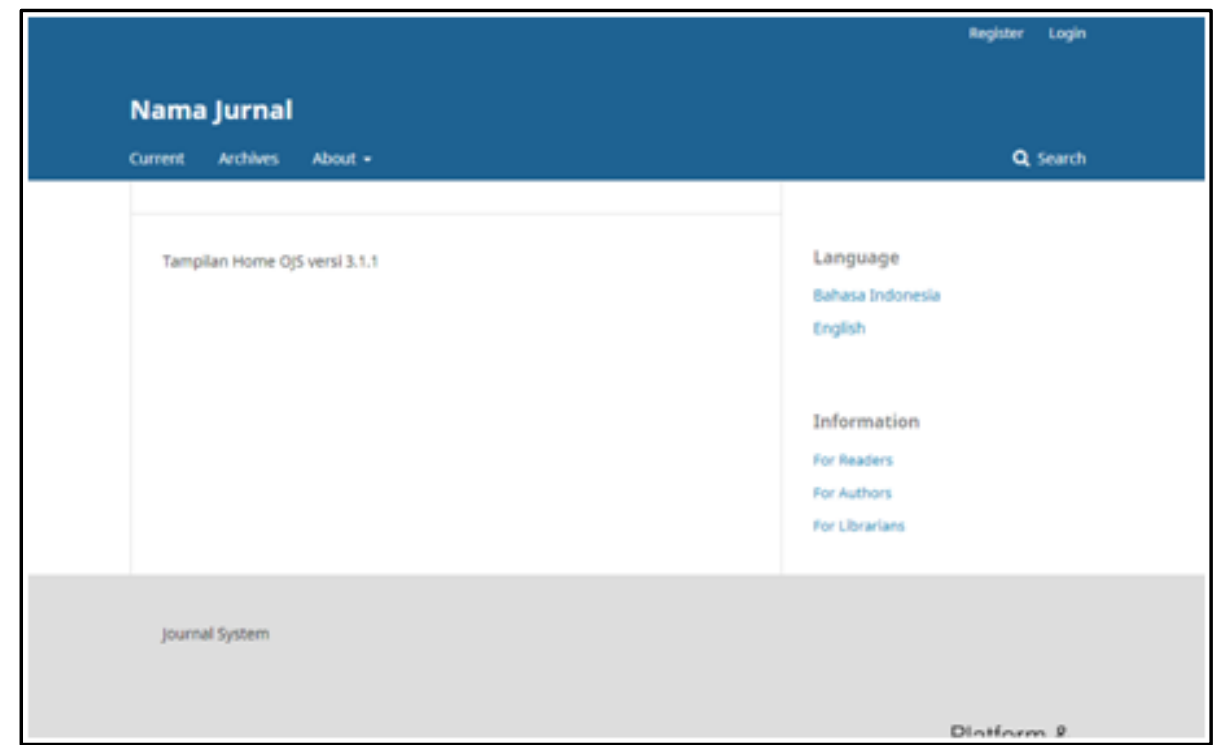

Gambar 17. Halaman Home Jurnal.

Kemudian selanjutnya setelah berhasil melengkapi identitas jurnal, maka pengguna baik itu Admin, Author ataupun Reader sudah dapat membuka halaman Home dari jurnal yang dibuat oleh Admin. Pada halaman Home Jurnal, terdapat menu Register untuk melakukan pendaftaran sebagai Author dan Reader, serta menu Login untuk melakukan login menggunakan username dan password yang telah terdaftar.

5. Halaman Dashboard Admin 


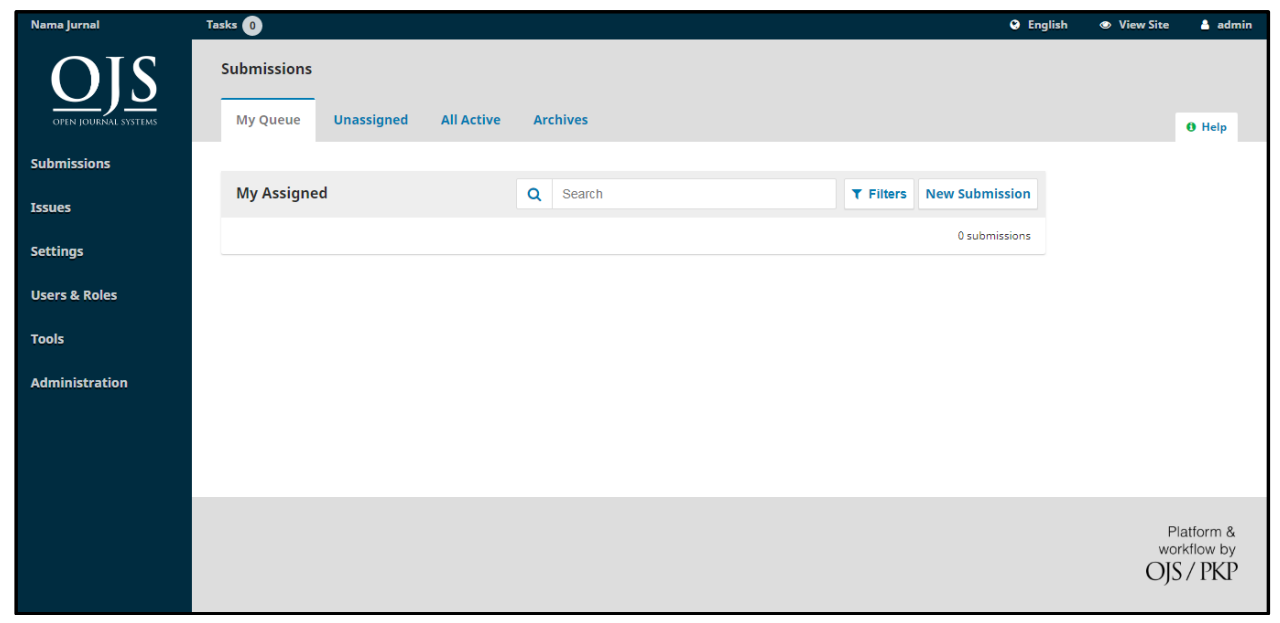

Gambar 18. Halaman Dashboard Admin.

Pada halaman Dashboard Admin terdapat menu Submissions yang berisi antrian artikel yang dikirimkan oleh Author. Menu Issues yang berisi terbitan terdahulu dan terbitan jurnal yang akan datang. Menu Settings berisi pengaturan jurnal, website, workflow dan distribution. Menu Users \& Roles terdiri dari menu Users yang berisi daftar nama pengguna yang sudah terdaftar pada jurnal tersebut serta menu Roles yang merupakan daftar peran pengguna, salah satu kelebihan dari OJS versi 3 yaitu memiliki peran pengguna yang lebih fleksibel dan sistem manajemen tugas. Menu Tools berisi menu untuk importlexport plugin seperti tema, dan menu Administration untuk mengatur administrasi situs dan jurnal.

6. Halaman Register (untuk Reader dan Author)

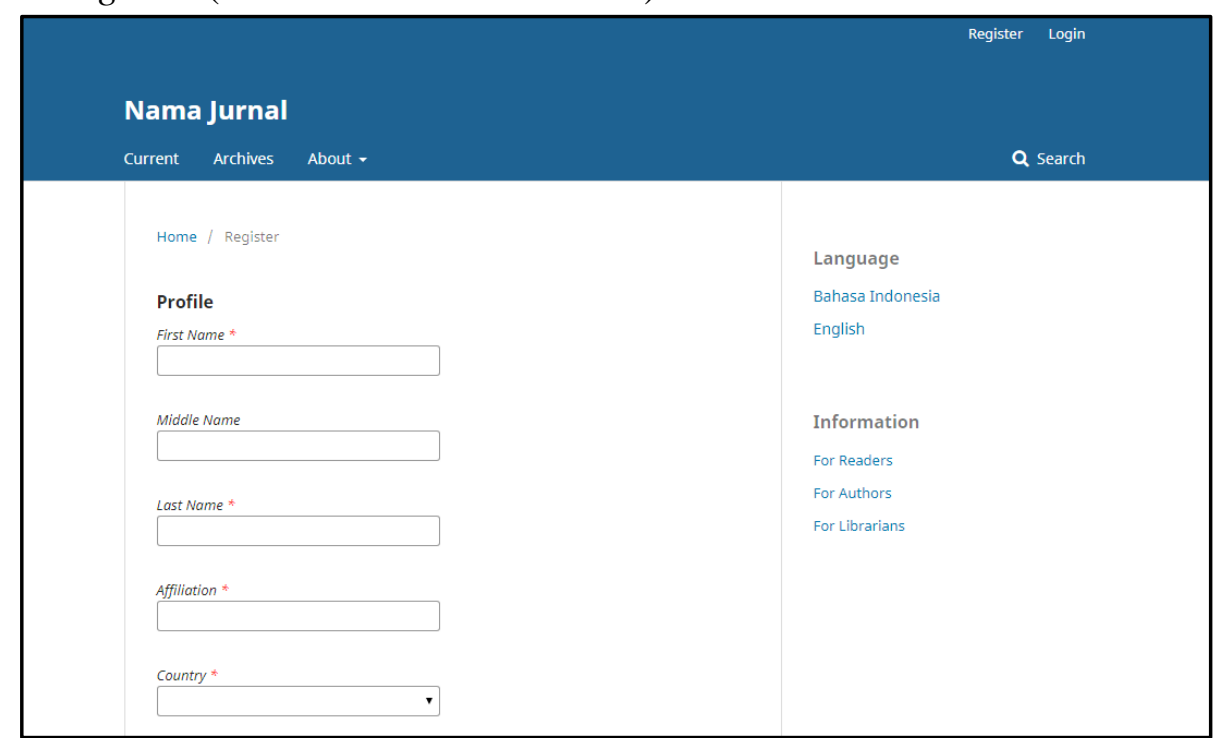

Gambar 19. Halaman Register.

Pada halaman Register terdapat form yang harus dilengkapi oleh pengguna untuk melakukan pendaftaran sebagai Author. Pada halaman Register ini pengguna juga dapat melakukan permintaan untuk berperan sebagai Reviewer.

7. Halaman Submissions (untuk Author) 
Pada halaman Submissions merupakan halaman yang digunakan Author untuk melakukan submit article (pengiriman artikel).

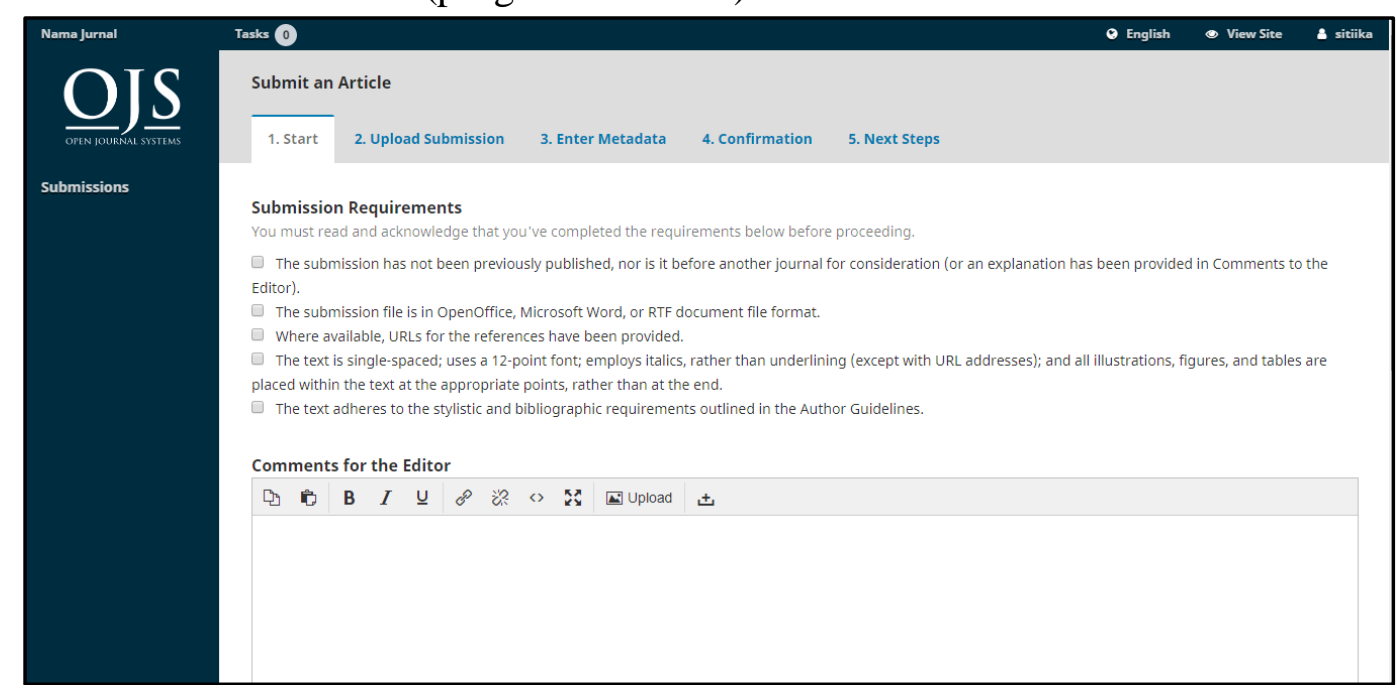

Gambar 20. Halaman Submissions.

8. Halaman Dashboard Author

Pada halaman Dashboard Author terdapat menu My Queue, berisi artikel yang sedang dalam proses penugasan serta menu Archives, berisi arsip artikel yang pernah dikirimkan oleh Author. Pada halaman Dashboard Author ini Author juga dapat memantau status dari artikel yang sudah dikirim oleh Author, misalnya artikel sedang dalam proses review atau sudah melalui tahap untuk penerbitan.

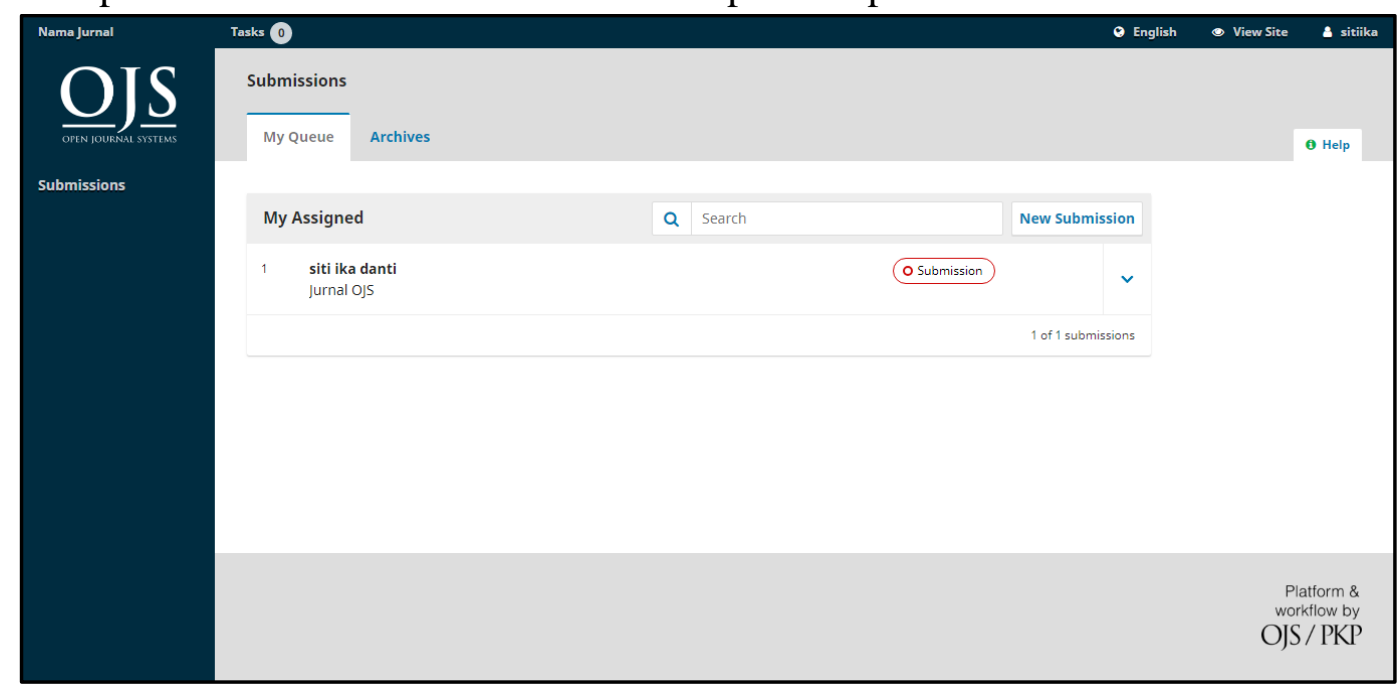

Gambar 21. Halaman Dashboard Author.

\section{Halaman Dashboard Journal Editor}

Pada halaman Dashboard Journal Editor berisi menu Submissions, Issues, Settings, Users \& Roles dan Tools yang sama seperti pada halaman Dashboard Admin dan yang membedakan hanya menu Administration tidak ada pada halaman Dashboard Journal Editor. 


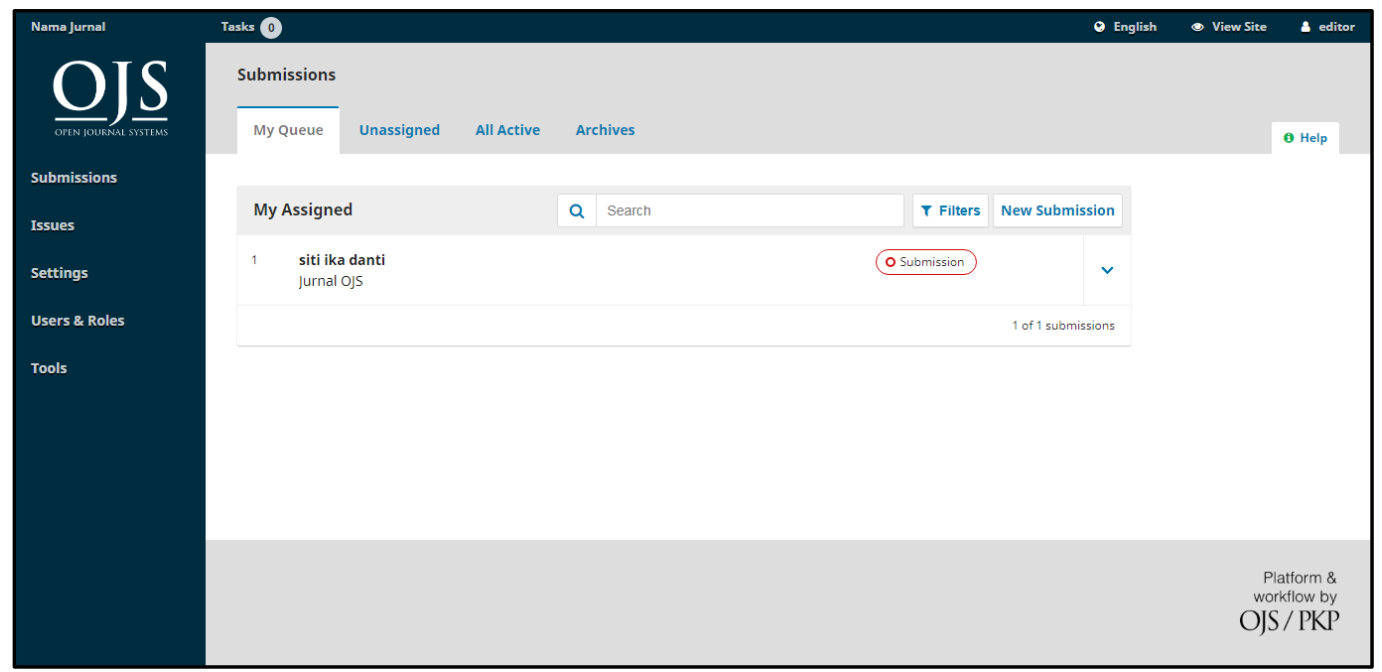

Gambar 22. Halaman Dashboard Journal Editor.

\section{Halaman Dashboard Reviewer}

Pada halaman Dashboard Reviewer terdapat menu My Queue yang berisi artikel jurnal yang ditugaskan oleh Editor untuk dilakukan review, serta menu Archives yang berisi artikel jurnal yang telah selesai di-review.

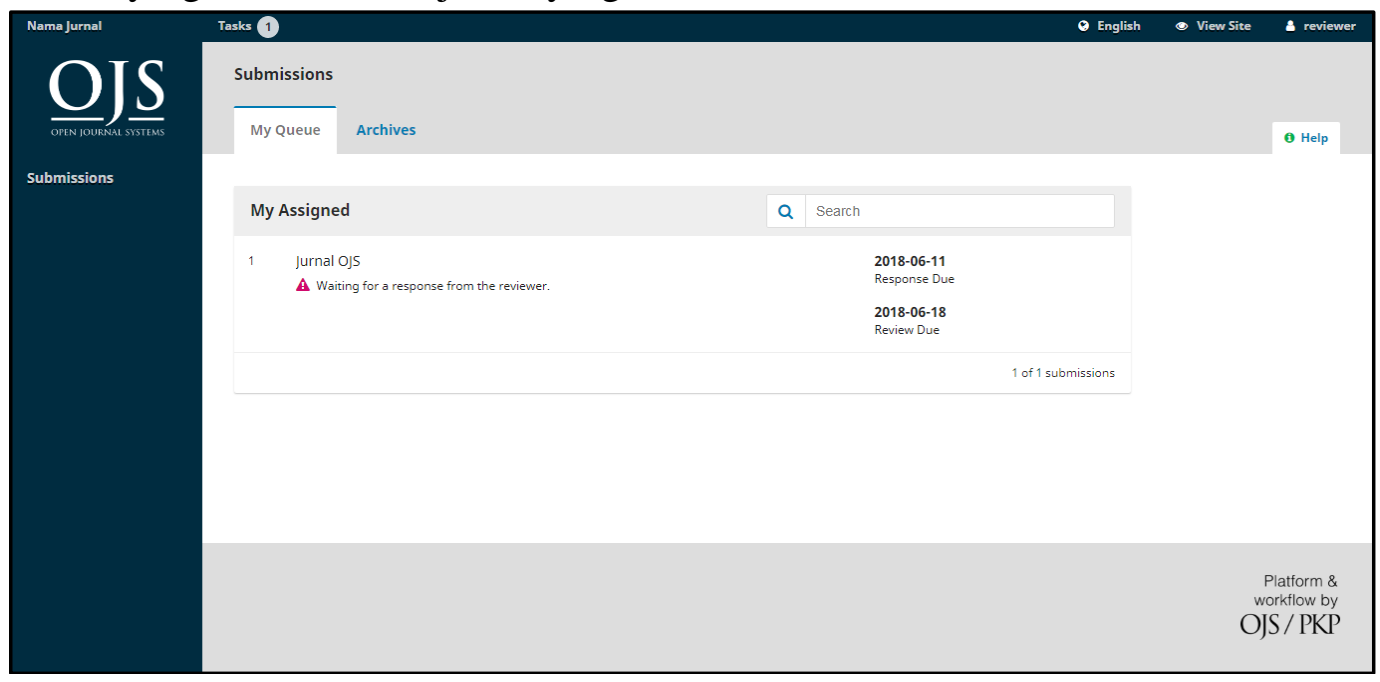

Gambar 23. Halaman Dashboard Reviewer.

\section{KESIMPULAN}

Kebutuhan yang diperlukan untuk proses instalasi OJS versi 3 yaitu web browser, akun web hosting dan tentunya file instalasi OJS versi 3. Terdapat 7 (tujuh) langkah untuk melakukan proses instalasi OJS versi 3, yaitu: (1) Upload file instalasi OJS pada direktori web hosting; (2) Ekstrak file instalasi OJS; (3) Buat folder "ojsdata"; (4) Buat database baru pada akun hosting; (5) Buka halaman website untuk melakukan instalasi OJS; (6) Install OJS; (7) Tahap terakhir setelah proses instalasi OJS berhasil dilakukan, maka tampil pemberitahuan instalasi OJS berhasil. Kelebihan dari OJS versi 3 yaitu antarmuka pengguna yang sudah disempurnakan, sistem navigasi, keahlian dalam tema, alur kerja pada OJS versi 3 sangat dinamis dan jauh lebih dapat disesuaikan daripada OJS 2, serta memiliki peran pengguna yang lebih fleksibel dan sistem manajemen tugas. Sehingga dapat mendukung dan memberi kemudahan dalam kegiatan pengelolaan dan publikasi jurnal ilmiah secara online. 


\section{SARAN}

Berdasarkan penelitian yang telah dilakukan, saran yang dapat dijadikan sebagai bahan pertimbangan untuk meningkatkan pengelolaan dan publikasi jurnal ilmiah yaitu perlu adanya sistem e-journal yang lebih dinamis dan fleksibel. Sehingga dapat mempermudah pengguna baik itu Admin, Journal Editor, Reviewer, Author ataupun Reader dalam melakukan proses pengelolaan dan publikasi jurnal ilmiah.

\section{DAFTAR PUSTAKA}

[1] Aryani, D., Wahyudin, M., \& Fazri, M. (2015). PROTOTYPE ROBOT CERDAS PEMOTONG RUMPUT BERBASIS RASPBERRY Pi B+ MENGGUNAKAN WEB BROWSER. CERITA Journal, 1(1), 1-10.

[2] Ariyus, D., \& Anggara, F. A. (2018). ANALISIS PERBANDINGAN METRIKS PADA EXPIRED DOMAIN TERHADAP INDEXING GOOGLE STUDI KASUS WEBSITE BERBASIS GALLERY. SEMNASTEKNOMEDIA ONLINE, 6(1), 1-3.

[3] Rahayu, N., Lestari, F. H. N., \& Aprilyani, U. T. (2017). Clothing Sales Information System Web-Based:“Bluelight Distro". VOLT: Jurnal Ilmiah Pendidikan Teknik Elektro, 2(1), 55-62.

[4] Baihaqi, M., \& Hanafi, A. PERANCANGAN DAN PEMBUATAN E-JOURNAL MENGGUNAKAN OPEN JOURNAL SYSTEM DI STMIK JENDERAL ACHMAD YANI YOGYAKARTA.

[5] Wijaya, N. H. (2017). PENGEMBANGAN E-JOURNAL HASIL PENELITIAN MAHASISWA FAKULTAS ILMU KESEHATAN UNIVERSITAS RESPATI YOGYAKARTA. Jurnal Teknologi Informasi Respati, 9(26).

[6] Fajrin, N., Kamelia, L., \& Juhana, T. (2018, January). Instalasi dan Implementasi Open Journal System di Local Area Network Laboratorium Telematika STEI-ITB. In Prosiding-Seminar Nasional Teknik Elektro UIN Sunan Gunung Djati Bandung (pp. 18-29).

[7] Sani, M., (2016). Penerapan Ilearning Journal Center (iJC) Berbasis Open Journal System (OJS) Sebagai Media Penerbitan E-journal Pada Perguruan Tinggi. Skripsi Jurusan Sistem Informasi. Perguruan Tinggi Raharja. Diakses dari: http://widuri.raharja.info/index.php/SI1311475690 (16 Mei 2018).

[8] Handayani, I., Aini, Q., \& Sari, N. (2018). Pemanfaatan Sistem iJC Berbasis OJS Sebagai Media E-Journal Pada STISIP YUPPENTEK. Technomedia Journal, 2(2), 90-102. 